\title{
Job Satisfaction of Female Teachers in Dharwad District of Karnataka
}

\author{
Pooja $^{1^{*}}$ and Ganga V. Yenagi ${ }^{2}$ \\ ${ }^{1}$ Department of Human Development and Family Studies, College of Community Science, \\ University of Agricultural Sciences, Dharwad, India \\ ${ }^{2}$ Department of Agricultural Extension Education, College of Agriculture, \\ UAS, Dharwad, India \\ *Corresponding author
}

K e y w or d s
$\begin{aligned} & \text { Job satisfaction } \\ & \text { and primary } \\ & \text { school teachers }\end{aligned}$
Article Info
$\begin{aligned} & \text { Accepted: } \\ & \text { 15 December } 2019 \\ & \text { Available Online: } \\ & \text { 20 January } 2020\end{aligned}$

\section{Introduction}

Human beings like all other organisms seek satisfaction rather than deprivation. This

satisfaction is derived from situational,
Human beings like all other organisms seek satisfaction rather than deprivation. It is a feeling of well-being or pleasure when you have fulfilled a desire or covered a need. In achieving satisfaction, the mental functioning of the human being is in harmony. Satisfaction contributes to happiness while, on the contrary, dissatisfaction generates suffering. In our society, teaching is one of the best and noble professions and the teacher is a prominent personality in this world. Among all levels of teachers, primary school teachers are those who play a vital role in nurturing the young minds. So, teacher has a significant role in making the students life bright and productive. The present study was conducted with a purpose of determining "job satisfaction of primary school teachers in Dharwad district" and to assess the factors influencing the job satisfaction of teachers. The sample comprised of 54 female teachers which randomly selected from six purposively selected primary schools in Dharwad district. Job satisfaction scale developed by Kanungo (1982) was used to measure the levels of job satisfaction of primary school teachers. In this study, Karl Pearson's Correlation was used to assess the relationship of independent variables with job satisfaction. The t-test was used to assess the difference between age, religion, education, type of school and locale of school. ANOVA for Length of service and pay package with regarding job satisfaction. It showed that majority of the teachers were highly satisfied with their job. Results also revealed that type of School and pay package of teachers were positively and significantly related to job satisfaction of primary teachers. The t-test revealed that there were significant differences found between type of school (Government and private) in terms of Job satisfaction of primary school teachers. It indicated that private school teachers were more satisfied with their job compared to government school teachers. Analysis of variance indicated that there were no significant difference found between pay package and length of service in terms of job satisfaction. behavioral and personality factors. It is a feeling of well-being or pleasure when you have fulfilled a desire or covered a need. In achieving satisfaction, the mental functioning of the human being is in harmony. 
Satisfaction contributes to happiness while, on the contrary, dissatisfaction generates suffering.

It is generally considered that teachers are the pillars of our society because they shoulder the responsibility of educating and training students upon whom our future relies. We believed that a teacher, considered as an engineer of the human soul, plays an important role in society. Teaching is one of the best and noble professions and the teacher is a prominent personality in this world. Among all levels of teachers, primary school teachers are those who play a vital role in nurturing the young minds. So, teacher has a significant role in making the students life bright and productive. The quality of teaching depends upon active, dedicated and satisfied teachers. The teachers who are satisfied with their job can perform their responsibilities with more concentration and devotion. It is an established fact that a satisfied teacher puts his/her best efforts to make teaching more effective. Job satisfaction positively influences the teacher's performance, student's achievement, organizational commitment and as well as work motivation. Job satisfaction is a source of motivation that sustains efforts in performing tasks required of good teachers (Watson et al., 1991).

Teacher's job satisfaction is one of the key factors in school dynamics and is generally considered as a primary dependent variable in terms of which effectiveness of the school is evaluated. The well-adjusted and satisfied teacher can contribute a lot to the well-being of his/her students and shape the nation's destiny. Job satisfaction is a general attitude of an individual towards his/her job. Positive attitudes towards the job are equivalent to job satisfaction, whereas negative attitudes towards job are equivalent to job dissatisfaction (Holeyannavar and Khadi 2013). Hence, present study was taken up to assess the levels of job satisfaction of primary teachers.

\section{Materials and Methods}

Three urban locality schools and three rural locality schools in Dharwad district of Karnataka were purposively selected. A sample of 54 female primary school teachers was selected for the study.

Job Satisfaction Scale developed by (Kanungo1982) was used to assess the job satisfaction of primary school teachers. The responses were required to indicate the degree of their satisfaction or dissatisfaction with each of the job qualities as one relates to the present job. It is a 6 point scale consisting of 16 statements. The 6 answer categories are 'extremely satisfied', 'moderately satisfied', 'mildly satisfied', 'mildly dissatisfied', 'moderately dissatisfied' and 'extremely dissatisfied' with a scoring of $6,5,4,3,2$, and 1 respectively with a minimum score of 16 and maximum of 96 . The total job satisfaction scores will be calculated and categorization will be made as low (16-42), average (43-69) and high (70-96) levels of job satisfaction.

Descriptive statistics were used to describe the job satisfaction and other independent variables. To study the relationship between the job satisfaction and independent variable of primary school teachers, Karl Pearson's correlation coefficient was used. T-test and ANOVA was used to know the difference between the groups of variables in terms of job satisfaction. The questionnaires were handed over to teachers after informed consent was obtained.

\section{Results and Discussion}

It was revealed from the above table that more than half of the sample comes under the Middle adult age group i.e.42-56. Among the 
samples selected for the study, majorities $(77.77 \%)$ of them were belonging to Hindu religion and $22 \%$ were from Muslim religion. Seventy percent of the respondents were graduated and twenty percent were post graduated. Among the samples, majority of the teachers were from private schools and having monthly salary below 14,000 rupees and having below 8 years of service. Results from table clearly depicts that $85 \%$ of the teachers were satisfied with their job.

Figures 1 represent the percentage of teachers on high, average, and low levels of their job satisfaction. It reveals that $85 \%$ of the teachers were highly satisfied with their jobs and $7 \%$ of the teachers had low job satisfaction.

Table.1 Percentage and frequency distribution of primary school teachers

\begin{tabular}{|c|c|c|}
\hline Variable & Category & Frequency (\%) \\
\hline \multirow[t]{2}{*}{ Age } & Young Adults & $26(48.14)$ \\
\hline & Middle adults & $28(51.85)$ \\
\hline \multirow[t]{2}{*}{ Religion } & Hindu & $42(77.77)$ \\
\hline & Muslim & $12(22.22)$ \\
\hline \multirow{2}{*}{ Education } & Graduation & 38 (70.37) \\
\hline & Post-graduation & $16(29.62)$ \\
\hline \multirow[t]{4}{*}{ Length of Service } & Below 8years & 19(35.18) \\
\hline & $9-15$ & $9(16.66)$ \\
\hline & $16-21$ & $15(27.77)$ \\
\hline & 22 and Above & $11(20.37)$ \\
\hline \multirow[t]{4}{*}{ Pay package } & Below 14000 & $22(40.74)$ \\
\hline & $15000-22000$ & $16(29.62)$ \\
\hline & 23000-30000 & $9(16.66)$ \\
\hline & $31000-38000$ & $7(12.96)$ \\
\hline \multirow[t]{2}{*}{ Type of School } & Government & 24(44.44) \\
\hline & Private & $30(55.55)$ \\
\hline \multirow[t]{2}{*}{ Locale of School } & Rural & 25(46.29) \\
\hline & Urban & $29(53.70)$ \\
\hline \multirow[t]{3}{*}{ Job satisfaction level } & Low(16-42) & $4(7.40)$ \\
\hline & Medium(43-69) & $7(12.96)$ \\
\hline & High(70-96) & $46(85.18)$ \\
\hline
\end{tabular}


Table.2 Correlation between Independent variables and Dependent variable

\begin{tabular}{|l|l|l|l|l|l|l|l|l|}
\hline Variables & $\mathbf{1}$ & $\mathbf{2}$ & $\mathbf{3}$ & $\mathbf{4}$ & $\mathbf{5}$ & $\mathbf{6}$ & $\mathbf{7}$ & $\mathbf{8}$ \\
\hline 1. Job satisfaction & 1 & - & - & - & - & - & - & - \\
\hline 2. Age & .056 & 1 & - & - & - & - & - & - \\
\hline 3. Religion & .230 & .158 & 1 & - & - & - & - & - \\
\hline 4. Education & -.023 & .138 & $.141^{*}$ & 1 & - & - & - & - \\
\hline 5. Length of service & .227 & $.728^{* *}$ & .231 & .059 & 1 & - & - & - \\
\hline 6. Pay package & $.291^{*}$ & $.655^{* *}$ & $.289^{*}$ & .144 & $.593 * *$ & 1 & - & - \\
\hline 7. Type of School & $.594^{* *}$ & .033 & $.299^{*}$ & .009 & .032 & .230 & 1 & - \\
\hline 8. Locale of School & .246 & -.077 & $.318^{*}$ & .114 & .075 & .123 & $.440^{* *}$ & 1 \\
\hline
\end{tabular}

Table.3 Descriptive statistics and difference between sub-groups of variables regarding to job Satisfaction

\begin{tabular}{|l|l|c|c|c|}
\hline \multicolumn{1}{|c|}{ Variable } & \multicolumn{1}{|c|}{ Sub-groups } & Mean(S.D) & Significance & t-value \\
\hline Age & Young Adult & $77.27(11.291)$ & .286 & .402 \\
\hline & Middle Adult & $78.79(15.878)$ & & \\
\hline Education & Graduation & $78.26(14.119)$ & .923 & \multirow{2}{*}{.169} \\
\hline & Post-graduation & $77.56(13.276)$ & & \multirow{2}{*}{$5.331 * *$} \\
\hline \multirow{2}{*}{ Type of School } & Government & $69(15.820)$ & .001 & \\
\hline & Private & $89.30(5.004)$ & & \multirow{2}{*}{1.833} \\
\hline
\end{tabular}

Table.4 ANOVA statistics for job satisfaction of Primary school teachers

\begin{tabular}{|c|c|c|c|c|}
\hline Variable & Sub-group & Mean(S.D) & F-value & Significance \\
\hline \multirow{4}{*}{$\begin{array}{l}\text { Length of } \\
\text { service }\end{array}$} & Below 8years & $74.47(12.158)$ & \multirow[t]{4}{*}{.972} & \multirow{4}{*}{.413} \\
\hline & $9-15$ & $76.22(16.453)$ & & \\
\hline & $16-21$ & $81.00(16.630)$ & & \\
\hline & 22 and Above & 81.73(8.799) & & \\
\hline \multirow[t]{4}{*}{ Pay-package } & Below 14000 & $71.95(17.900)$ & \multirow{4}{*}{2.674} & \multirow{4}{*}{.057} \\
\hline & $15000-22000$ & $82.38(5.252)$ & & \\
\hline & $23000-30000$ & $82.56(7.907)$ & & \\
\hline & $31000-38000$ & $81.57(12.882)$ & & \\
\hline
\end{tabular}


Fig.1 Percentage of teacher's level of job satisfaction

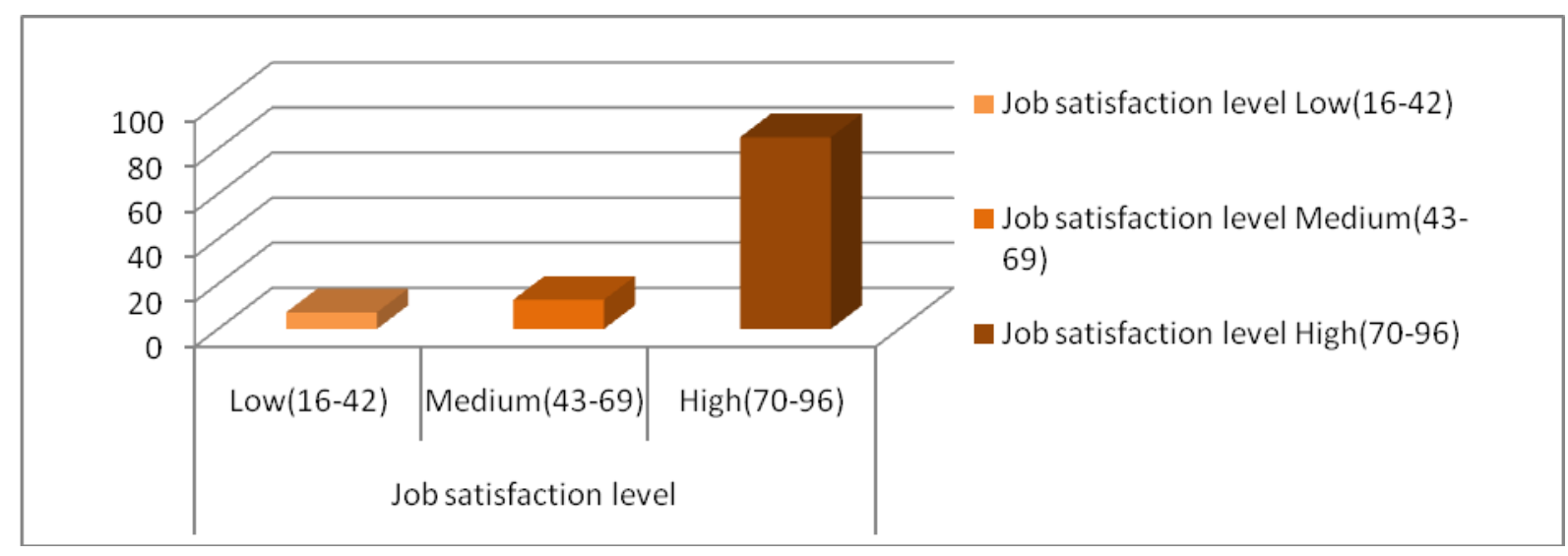

Table 2, reveals the relationship of Independent variables with job satisfaction of primary school teachers. The results represents that the pay package and type of school had positive and significant relationship with job satisfaction. It means higher the salary of the teachers, higher the level of job satisfaction. It is consistent with a study of (Pan et al., 2015), they found that higher monthly income was positively associated with Job satisfaction of university teachers.

From table 3, it was found that there was a significant difference between government and Private school teachers in their job satisfaction level. These results are in line with the findings of (Chandramma2013) revealed that Teachers working in Private management institutions expressed higher level of job satisfaction as compared to the government Institutions.

Other variables like age and education were found to be non-significant which were supported by the findings obtained by (Rama and Renuka, 2016) who revealed that age and Education had no significant influence on Job satisfaction.

Table 4 shows that, there was no significant differences found in the levels of job satisfaction in terms of Length of service and Pay package of teachers. These results are supported by the findings of Barman and Bhattacharya (2017), who stated that Monthly income had no statistically significant influence on overall job satisfaction of teachers working in different types of B.Ed. colleges. In the study of (Kardam and Rangnekar, 2012) who found that, there was no significant difference in different experience groups in their Job satisfaction.

From the above results and discussions, it was concluded that majority of the teachers exhibited high level of job satisfaction. Teacher's pay package and the type of school in which they were working found to be positively and significantly related to their job satisfaction. Teachers differed significantly in their job satisfaction with reference to type of school (Government and private). It indicated that private school teachers were more satisfied compared to the government school teachers.

\section{References}

Barman P, and Bhattacharyya D, (2017) Job Satisfaction of Teacher Educators in different Types of B.Ed. colleges in West Bengal. IOSR-Journal of Humanities and Social Sciences 22(2): 
80-99.

Holeyannavar G.P, and Khadi B.P. (2013) Interrelationship of marital and job satisfaction of

University Teachers. Karnataka Journal of Agricultural Sciences 26(2): 299-302.

Kanungo R, (1982) Job Satisfaction Scale. Int. J. Psychol. 23(3):165.

Kardam L.B, and Rangnekar S, (2012) Job Satisfaction: Investigating the role of Experience and Education. Journal of Arts, Science, \& Commerce 4(1): 16-22.

Pan B, Shen X, Liu L, Yang Y, and Wang L, (2015) Factors associated with job
Satisfaction among University Teachers in Northeastern Region of China: A Cross-Sectional Study. Int. J. Environ. Res. Public Health: 12762-12771.

Rama T.N, and Renuka P, (2016) A study on Job satisfaction of Post graduate teachers working in A.P.Model Schools. IOSR-Journal of Research and Method in Education 6(3): 43-48

Watson A, Hatto N, Squires D, and Soliman I, (1991) School staffing and the quality of Education: Teaching Adjustment and satisfaction. Teaching and Teaching Education, 7, 63-77.

\section{How to cite this article:}

Pooja and Ganga V. Yenagi. 2020. Job Satisfaction of Female Teachers in Dharwad District of Karnataka. Int.J.Curr.Microbiol.App.Sci. 9(01): 1405-1410.

doi: https://doi.org/10.20546/ijcmas.2020.901.155 